Article

\title{
Plant-Based Sustainable Development-The Expansion and Anatomy of the Medicinal Plant Secondary Processing Sector in Nepal
}

\author{
Filippo Caporale ${ }^{1,2}\left(\mathbb{D}\right.$, Jimena Mateo-Martín ${ }^{1,3}(\mathbb{D})$, Muhammad Faizan Usman ${ }^{1,4}$ and \\ Carsten Smith-Hall 1,*iD
}

1 Department of Food and Resource Economics (IFRO), University of Copenhagen, Rolighedsvej 25, 1958 Frederiksberg C., Denmark; filippo.capo@gmail.com (F.C.); jimena.mateo.martin@gmail.com (J.M.-M.); faizanusman@gmail.com (M.F.U.)

2 Institute for International Forestry \& Forest Products, Dresden University of Technology, Pienner Straße 7, 01737 Tharandt, Germany

3 Department of Land, Environment, Agriculture and Forestry (TESAF), University of Padova, Via dell'Università 16, 35020 Legnaro, Italy

4 Environmental Management of Ecosystems and Tropical Forests (GEEFT), AgroParisTech, 648 rue Jean-François Breton BP 7355, 34086 Montpellier CEDEX 4, France

* Correspondence: cso@ifro.ku.dk; Tel.: +45-2130-8683

Received: 26 May 2020; Accepted: 8 July 2020; Published: 10 July 2020

check for updates

\begin{abstract}
There is an increasing global demand for medicinal plants. Nevertheless, the nature and scale of processing in national-level medicinal plant production networks, and how this can contribute to sustainable development, are poorly understood. This study (i) uncovers and explains the emergence of the Nepalese medicinal plant secondary processing sector, (ii) characterises the enterprises and identify the obstacles they face, (iii) quantifies the volumes and values of processed species and end markets, and (iv) discusses the potential to contribute to sustainable economic development. Empirical data were generated from key informant interviews and qualitative $(n=13)$ and quantitative ( $n=79$ ) semi-structured surveys of medicinal plant processing enterprises. In 2014-15, the sector purchased 3679 metric tonnes of air-dry raw materials (across 67 products) for USD 4.0 million, producing 494 tonnes of end-products valued at USD 11.2 million. The sector is characterised by small enterprises. Rising domestic demand drove the increase in the number of enterprises. Key business obstacles were export barriers, low access to technology, infrastructure and service barriers, labour challenges, socio-economic and political instability, and the inefficient bureaucracy. The actions required to change from being a supplier of raw materials and producer of lower-value domestic consumer products to integrating into the global economy as an exporter of higher-value products that are sustainably sourced are discussed.
\end{abstract}

Keywords: bioeconomy; Himalayas; medicinal and aromatic plants (MAPs); processing; small and medium enterprises (SMEs); value addition

\section{Introduction}

There is general agreement in the literature that the global demand for medicinal plants is substantial and growing. For instance, data on medicinal plants in the Harmonised Commodity Description and Coding System (code HS 121190) indicate a global export of USD 2.6 billion in 2016 [1], while global trade in medicinal plants and their derivatives has been estimated at USD 33 billion in 2014 with annual growth rates of $2.4 \%$ in volume and $9.2 \%$ in value [2]. Using the terminology of [3], user demand is increasing in response to changes in medicinal plant supplies, 
user characteristics, the type and level of threat, and the available healthcare options. While raw material amounts are decreasing for some products due to overharvesting in the wild [4], increased supplies are expected through a rise in the number of cultivated species as prices increase [5] and knowledge about cultivation accumulates [6]. Moreover, it should be noted that species substitution in response to decreasing supplies is widespread, such as in Ayurveda [7]. User characteristics include a positive correlation between income and traditional medicine consumption in the Global North [8] and widespread preference in the Global South, e.g., through the association of traditional medicines and better health care [9]. It also appears that traditional medicine is used across a wide range of diseases, including, in some cases, in the face of epidemics [10]. Despite all these indications of high and growing medicinal plant demand, there are almost no studies of medicinal plant enterprises: what characterises such enterprises? What are their economic contributions? What obstacles and opportunities do they face? Most related studies focus on household incomes, cultivation, or value chains $[11,12]$ with medicinal plant enterprises and secondary processing remaining in the dark. The few existing medicinal plant enterprise studies focus on reviews of allied subjects [13] such as resource management, do not use data derived from enterprises [14], or refrain from making explicit analysis of enterprises [15]. In addition, enterprises are excluded from medicinal plant reviews, such as the otherwise excellent recent review of Asian medicinal plants in [16]. A separate strand of the literature focuses on enterprises and non-timber forest products [17-19] but does not provide specific medicinal plant enterprise information. There is, however, a limited but growing body of literature documenting the transformation and commercialisation of traditional medicine systems, aimed at making standardised high-quality products widely available. This includes description of the transformation and increase in medicinal plant demand in Tibet [20], driven by new legislative requirements for the Tibetan system of healing (Sowa Rigpa), apparently linked to concerns regarding drug and patient safety. Within two decades, Sowa Rigpa transited from the local and traditional to the global and modern, with annual sales growing tenfold to USD 678 million from 2000 to 2017 [21]. Ayurvedic and Unani medicine have similarly transited to a modern industry in India [13,22] and beyond [23], including a steady rise in the number of processing units that operate with a profit [24]. A similar pattern has been documented in South Africa where higher medicinal plant consumption is associated with the commercialisation of traditional knowledge and the development of new products as part of an emerging formal natural products sector [25].

Nepal is a major supplier of raw materials to the medicinal plant industries in India and China; trade encompasses up to 300 species [26] and the annual export has been estimated to be between 7000 and 27,000 tonnes at a value of USD 11 to 48 million (in 2020 value, inflation-adjusted figures derived from [27]). At the district level, harvester income from medicinal plant sales has been documented to surpass the annual district budget [28].

Historically, there has been almost no domestic secondary processing of medicinal plants in Nepal; however, the number of domestic medicinal plant enterprises increased from 16 in 1998 [29] to 77 in 2011 [30] to somewhere between 233 and 325 in 2019 [31]. In principle, each stage of the production process-collection, cultivation, processing, marketing, value addition, and manufacturing — provides opportunities for the creation of new enterprises [13]. While there have been few studies of these enterprises in Nepal [12], it is known that they: (i) are clustered, with around half the population located in the Kathmandu Valley [31]; (ii) are mainly smaller and privately owned enterprises [30-33]; (iii) are likely to obtain most raw materials from within-country harvests [32,34] through the well-established national production network for medicinal plants [35,36]; (iv) benefit, at least on paper, from a pro-enterprise policy framework [32,37-39]; (v) may to some degree have access to financial and technical support provided by the government and development partners [32]; (vi) appear to suffer from poor public governance, including bureaucratic delays and confusion regarding procedures and the required documentation [32]; and (vii) could benefit from a global growing demand, especially from India and China [2,29,30,32,40,41]. According to [1], medicinal plant-related industries account for at least $5 \%$ of Nepal's total gross domestic product. These enterprises have a role in providing 
alternative sources of income, employment and distribution of wealth, as has been documented in other parts of the Global South [42]. Yet, there has been no study explaining the rapid increase in the number of processing enterprises in the past two decades, and details on the sector are scant, e.g., knowledge of enterprise characteristics and what species are processed.

Assessing the role of the processing industry in relation to sustainable economic development is difficult. On one hand, there are ample historical and contemporary claims [12] of unsustainable wild harvesting due to commercial demand, such as through premature harvesting or overharvesting, as traditional management systems break down with increasing demand [26]. On the other, the empirical basis for supporting many of these claims is not strong [43] though slowly improving on a species-by-species basis, e.g., for Paris polyphylla Sm. [4,44]. An improved understanding of the domestic processing sector will allow a more in-depth discussion of the relative importance of this sector in relation to sustainable economic development, e.g., through knowledge of what species are in demand and an assessment of this demand vs. overseas demand.

This study is the first national-level investigation of medicinal plant enterprises, and the first to derive primary data from enterprises themselves rather than from secondary sources, and aims to (i) uncover and explain the reasons for the emergence of the Nepalese medicinal plant secondary processing sector since the late 1990s, (ii) characterise the enterprises and identify the obstacles they face, (iii) quantify the production network in terms of species processed, the associated volumes and values, and end markets (domestic or export), and (iv) discuss the potential for the processing sector to contribute to sustainable economic development.

\section{Materials and Methods}

\subsection{Terminology and Definitions}

Here we think of sustainable economic development as part of the bioeconomy, following the bio-resource school [45] with its central attention to the processing and conversion of bio-resources, such as medicinal plants, into new products while emphasising the simultaneous achievement of economic growth and environmental sustainability. Businesses have a role in biodiversity conservation [46]. Within the bioeconomy, the production network refers to the nexus of interconnected functions, operations, and transactions [47] through which commercial medicinal plants are produced, distributed, and consumed. Medicinal plants are "plants, fungi, and lichens traded to produce pharmaceuticals, dietary supplement products, natural health products, cosmetics, and other personal care products, and culinary products" [48] (p. 14); fungi and lichens are included alongside plants as these are part of the same production networks $[35,36]$. Due to the widespread uses of medicinal plants, the medicinal plant production sector is not equivalent to or a subset of the pharmaceutical industry. Within the medicinal plant industry, our focus is on enterprises undertaking secondary processing. These enterprises are usually small-scale businesses, widespread in plant-dependent localities in lower income countries where they contribute to local economies [49]. Following [50-52], primary processing consists of simple low-skill operations, such as cleaning and air-drying, taking place locally after collection, while secondary processing requires purchased inputs (such as oil or alcohol for lotions and tinctures), technologies (e.g., solvent extraction of essential oils), and specialised skills (e.g., to complete the process of distilling). Finally, we apply the actor terminology for economic agents in the Himalayan plant trade proposed by [53], distinguishing harvesters, traders, and wholesalers.

\subsection{Study Area}

Nepal $\left(26^{\circ} 20^{\prime}-30^{\circ} 35^{\prime} \mathrm{N}\right.$ latitude, $80^{\circ} 05^{\prime}-88^{\circ} 10^{\prime}$ E longitude, $60-8848 \mathrm{~m}$ a.s.l., $\left.147,181 \mathrm{~km}^{2}\right)$ is a recently established federal republic made up of 77 districts organised into seven provinces (three of which are not yet named). In terms of biodiversity, the country is part of six floristic provinces and over $2 \%$ of the world's flowering plants are found in 118 ecosystems, including 35 forest types [54]. Kathmandu Valley (in Bagmati Province) is the country's dominant urban centre, home to major 
industries such as food and beverage processing, garments and carpets, bricks and construction materials, finance, tourism, and machinery [55]. The Valley is also an important node in the medicinal plant production network [56] and home to around $50 \%$ of the secondary medicinal plant processing enterprises in the country [31]. It is not known whether enterprises differ across the country, e.g., inside and outside the Valley.

\subsection{Analytical Framework}

To investigate the emergence of the Nepalese medicinal plant secondary processing sector and quantify key variables, such as volumes of raw materials at the species level, the analytical framework in Figure 1 was developed and applied. It draws on recent work to determine what conditions are needed to make small and medium forest enterprises thrive [17] and work applying global production network (GPN) theory [57] to medicinal plant production networks in Nepal [28,36].

\section{Context: Medicinal Plant Production Network in Nepal}

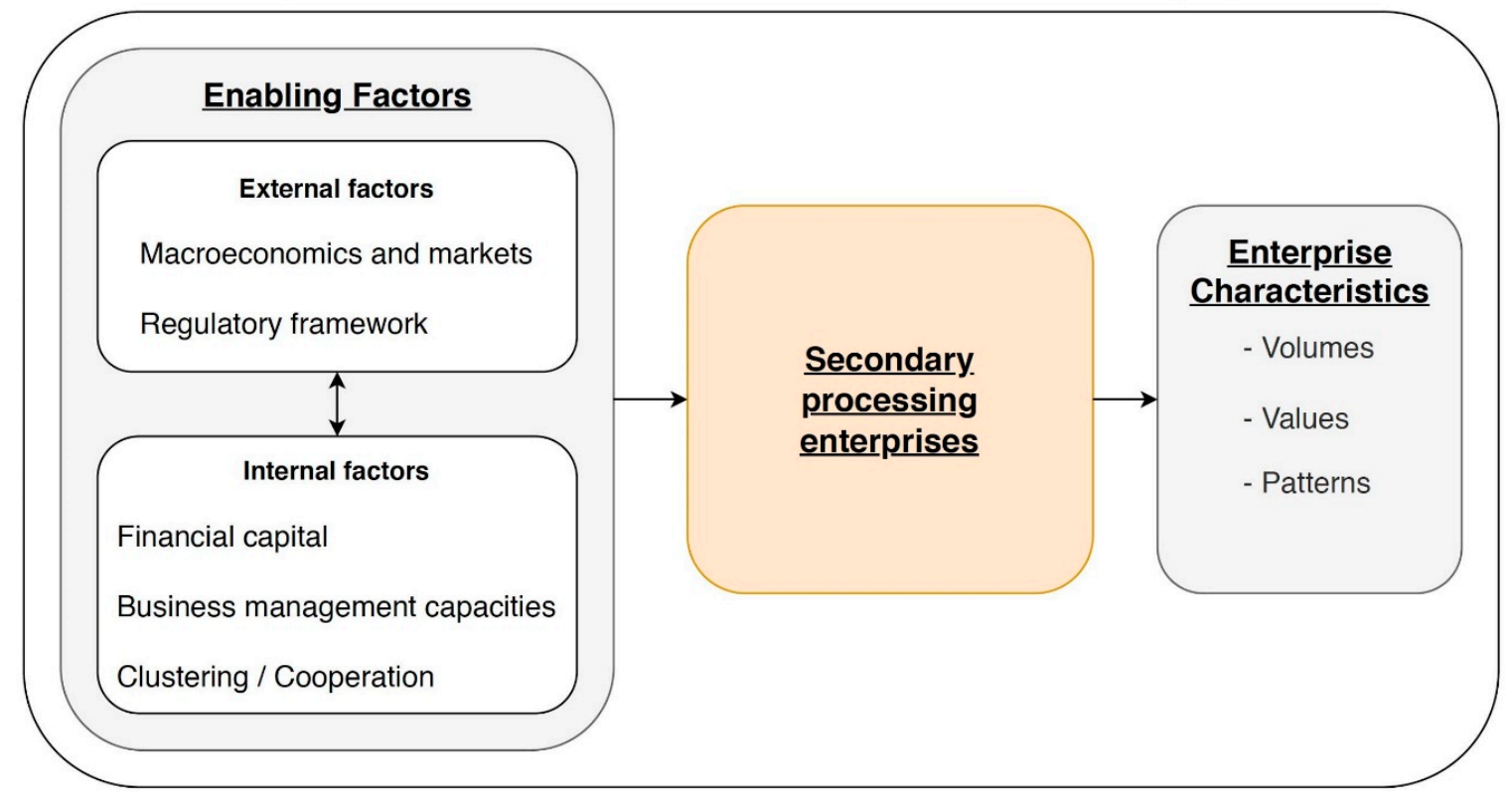

Figure 1. Analytical framework for investigating secondary processing enterprises in the medicinal plant production network in Nepal: factors promoting and/or hindering establishment and operation (derived from [17]) and quantification of key enterprise characteristics (based on [36]).

Specifically, a recent review of the commercial medicinal plant literature in Nepal was used [12] to focus the analysis of secondary processing enterprises on five of the external (characteristics of the economic environment) and internal (related to capabilities of enterprises) critical success factors described in [17]. An overview of the indicators developed for each enabling factor is provided in Section 3.1. Then, an instrumental use of the GPN toolbox [36] was made through the analytical application of the value creation function (species processed, volumes and values of raw materials and consumer products) and explicit discussion of the potential to contribute to sustainable economic development.

\subsection{Data Collection and Analysis}

Data on the enabling factors were collected using key informant interviews and a semi-structured questionnaire. Five key informants were identified and interviewed: the president and senior vice-president of the Nepal Herbs and Herbal Products Association (NEHHPA), the vice-president of the Herbal Entrepreneurs Association of Nepal (HEAN), the chairman of the Ayurvedic Medicine Producers Association of Nepal (AMPAN), and the owner of a secondary processing enterprise that had 
closed down. All interviews were open-ended, implemented as a dialogue, and provided contextual understanding that informed the design of the semi-structured questionnaire (Supplementary Materials, Table S1). Each of the five factors were divided into a number of sub-topics (2-17 per factor) identified from existing descriptions of the medicinal plant production network in Nepal [12,26,28,32,35-38]. Each variable included an open-ended question allowing for wider discussion and a closed question where respondents graded (using a 1-5 Likert scale) the importance of that subtopic. The questionnaire population consisted of the 47 secondary processing enterprises previously interviewed by the Transiting to Green Growth in Nepal (TGG-N) project (see [48]), drawn from the 98 enterprises confirmed to operate in the Kathmandu Valley [31]. All 47 companies were contacted by phone or email and invited to participate: 12 enterprises were not reachable (no answer), 20 said no (Chief Executive Officer (CEO) not available or willing), and 2 had been selected as key informants, resulting in 13 interviews. These were recorded and transcribed. Common themes were identified and analysed for patterns in relation to the establishment and operation of the enterprises. The mean, standard deviation, median, and mode were calculated for the graded questions.

The data to quantify the secondary processing enterprises' characteristics were collected as part of the TGG-N project through interviews ( $n=79$, from the total confirmed population of 233) based on a three-stratum sampling of the population (Table 1). Large enterprises were identified in dialogue with traders and all were approached, resulting in $n=8$ (out of 10 possible); they are treated in their own stratum to avoid possible inaccuracies when scaling up. Small enterprises outside the Kathmandu Valley were interviewed as part of the country-wide trader and central wholesaler data collection detailed in [48], resulting in $\mathrm{n}=30$ (out of 132 enterprises) located in the Rupandehi, Rautahat, Makwanpur, Chitwan, Banke, Salyan, Taplejung, Dang, Palpa, Humla, and Morang districts. For the Kathmandu Valley, interviews were undertaken with a random sample of $n=41$ (out of 91). The full data collection instrument is included in [48]. Interviews were undertaken with the equivalent of the CEO or his representative. Descriptive statistics were calculated for each variable (volumes and values of purchased raw materials at species level, value of sold final products). The findings were generalised from sample to stratum subpopulations (large enterprises, small enterprises in Kathmandu Valley, small enterprises elsewhere) and then summed at national and provincial levels using the enterprise distribution reported by [31]. All values are in 2015 USD (102.41 NPR/USD).

Table 1. Medicinal plant secondary processing enterprises in Nepal: overview of strata and samples.

\begin{tabular}{cccc}
\hline Stratum & Subpopulation $^{\mathbf{1}}$ & \multicolumn{2}{c}{ Sample } \\
\cline { 3 - 4 } & & Raw Materials & End Products $^{\mathbf{2}}$ \\
\hline Large enterprises & 10 & 8 & 5 \\
Small enterprises-Kathmandu Valley & 91 & 41 & 4 \\
Small enterprises-other districts & 132 & 30 & 11 \\
\hline Totals & 233 & 79 & $20^{3}$ \\
\hline
\end{tabular}

${ }_{1}^{1}$ Size and distribution from [31]. ${ }^{2}$ End products sample was a subgroup of the raw materials sample. ${ }^{3}$ No. answering both volume and value questions; $\mathrm{n}=38$ for volume only.

\section{Results}

\subsection{Factors Promoting and Hindering the Establishing and Operation of the Medicinal Plant Secondary Processing Sector}

The key informants confirmed knowledge of the general operation of the commercial medicinal plant production network in Nepal: hundreds of species are mainly wild-harvested, an activity of particular importance to high altitude households, and traded through traders and wholesalers, with India being the main destination. Concerns were voiced regarding the sustainability of wild-harvested supplies and the need to increase cultivation. Trade may be legal or illegal, e.g., in circumvention of the Convention on International Trade in Endangered Species (CITES). After processing in India, higher-value products 
are imported back into Nepal, e.g., in the form of Ayurvedic medicine. Demand for medicinal plants from Nepal has increased manifold in the last two decades and while there has been some growth in secondary processing this falls far short of the potential due to a string of domestic constraints. The main enabling and constraining factors are (results of the questions in Table 2):

Increasing domestic demand. "Growing up in Nepal, I've been observing how more and more Nepalese are preferring jadibuti (medicinal herbs) over allopathic medicine and this is very good for our business," said a processor who also owns a pharmacy for traditional medicine. This is the driving force behind the emergence of the domestic medicinal plant secondary processing sector in Nepal, perceived to be much more important than increasing demands in India, China, or the rest of the world. This is also confirmed by the quantitative enterprise results, with a domestic demand score of $4.23 \pm 1.24$ (e.g., vs. $2.23 \pm 1.64$ for Indian demand). Domestic demand is believed to have increased as people are more aware of the benefits of using traditional medicinal plant products, as opposed to allopathic medicine. Domestic enterprises were claimed to have half the national market for Ayurvedic medicine, with the other half met by Indian imports.

Export barriers. While demand for medicinal plant products is likewise seen to be growing outside Nepal, exports to China and India are hampered by transportation costs, Chinese and Indian regulations, and inability to compete on prices with similar local goods. A lack of costly certifications - such as in Good Management Practices (GMP) or organic methods-impedes export to the EU, North America, and Japan; these markets have, however, been accessed by larger companies exporting certified essential oils. Several companies producing Ayurvedic medicine were reported to be in the process of getting GMP-certified to access overseas markets. Enterprises themselves also find certification to be important $(4.23 \pm 1.01)$. In general, Nepalese enterprises were perceived to lag behind Indian companies in terms of product marketing, confirmed by the enterprises (4.54 \pm 0.66$)$.

Technology and service barriers. Domestic companies are less competitive due to less productive processing and storage technologies (smaller companies cannot afford to import new technology) and a lack of supportive services and infrastructure, including the accredited laboratory testing of product quality and assistance to achieve certifications. Investments in public infrastructure (roads and telecommunications) would decrease the cost of raw supplies from remote areas. Enterprises emphasised the importance of access to technology $(4.62 \pm 0.96)$ and infrastructural improvements $(4.46 \pm 0.88)$.

Labour challenges. Enterprises in Nepal face labour shortages and high labour turnover caused by the outmigration of skilled males, also acting to drive up labour costs. This key issue was also emphasised by the individual enterprises $(4.62 \pm 0.77)$. In response, some companies train and hire female workers; a co-benefit is an improved social responsibility profile that helps in attracting European buyers concerned with women's empowerment. Another response is to hire unskilled workers which leads to inefficient production. Some larger companies respond by paying higher than the minimum wage, attracting labour and increasing loyalty and motivation.

Socio-economic and political instability. Business has been affected by a string of incidents, from national strikes during the Maoist insurgency to the 2015 Indian closure of the Nepalese border. Trade shocks can be sudden and unexpected, e.g., the promulgation of the CITES Act in 2017 [58] that unintentionally banned the trade of Nardostachys jatamansi (D. Don) DC. rhizomes. The importance of socioeconomic stability was emphasised by the enterprises $(4.54 \pm 0.66)$.

A cumbersome and inefficient bureaucracy. "Every department wants its piece of the pie," said one of the respondents about the government bureaucracy. The medicinal plant production network is burdened with official rules and regulations, creating a complex bureaucracy that results in a string of hurdles, such as delays in customs clearance. This system also enables widespread rent-seeking from police, forest officials, and other actors involved in approving trade and processing. One of the respondents stated: "Police disturbs transportation of raw material from one province to another and harasses the drivers." The requirements in connection to the auditing of exports and the payment of taxes were also seen as cumbersome and imposing unnecessary complex requirements on smaller 
enterprises. Private sector inefficiency was also pointed out: enterprises have difficulties in accessing bank credits, due to collateral requirements and high interest rates. Individual enterprises also gave importance to these issues, e.g., in relation to bureaucratic delays $(4.00 \pm 1.22)$ and rent-seeking behaviour $(3.83 \pm 1.34)$.

Key informants argued for the role of processor organisations (such as the NEHHPA, HEAN, and AMPAN) in tackling some of these barriers, such as by providing advice on legal requirements and promoting sales through creating a common brand under which enterprises can trade their products. Individual enterprises also found such coordination important (4.36 \pm 1.03$)$.

Table 2. Medicinal plant secondary processing enterprises $(n=13)$ in Nepal: an overview of external and internal enabling factors.

\begin{tabular}{|c|c|c|c|c|c|}
\hline Enabling Factors & Mean $\pm \mathrm{SD}^{1}$ & Median & Mode & Min & Max \\
\hline \multicolumn{6}{|c|}{ External: Macroeconomics and Markets } \\
\hline Domestic demand & $4.23 \pm 1.24$ & 5 & 5 & 1 & 5 \\
\hline Demand from China & $2.54 \pm 1.56$ & 2 & 1 & 1 & 5 \\
\hline Demand from India & $2.23 \pm 1.64$ & 1 & 1 & 1 & 5 \\
\hline Demand from the rest of the world & $3.15 \pm 1.86$ & 4 & 5 & 1 & 5 \\
\hline Prices of raw materials & $4.15 \pm 0.99$ & 4 & 5 & 2 & 5 \\
\hline Competitiveness with other companies & $3.31 \pm 1.32$ & 3 & 3 & 1 & 5 \\
\hline Presence of monopolies/oligopolies & $2.69 \pm 1.44$ & 3 & 3 & 1 & 5 \\
\hline Availability of new technologies & $4.62 \pm 0.96$ & 5 & 5 & 2 & 5 \\
\hline Variations of interest rate & $3.62 \pm 1.61$ & 4 & 5 & 1 & 5 \\
\hline China import regulations & $2.54 \pm 1.81$ & 1 & 1 & 1 & 5 \\
\hline India import regulations & $2.69 \pm 1.75$ & 3 & 1 & 1 & 5 \\
\hline Rest of the world import regulations & $3.15 \pm 1.72$ & 3 & 5 & 1 & 5 \\
\hline Import regulations in Nepal & $3.77 \pm 1.24$ & 4 & 5 & 2 & 5 \\
\hline Availability of skilled labour & $4.62 \pm 0.77$ & 5 & 5 & 3 & 5 \\
\hline Cost of labour & $4.31 \pm 0.75$ & 4 & 5 & 3 & 5 \\
\hline Improvement in infrastructure & $4.46 \pm 0.88$ & 5 & 5 & 3 & 5 \\
\hline Socio-economic stability & $4.54 \pm 0.66$ & 5 & 5 & 3 & 5 \\
\hline \multicolumn{6}{|c|}{ External: Regulatory Framework } \\
\hline Regulations and requirements & $4.38 \pm 1.33$ & 5 & 5 & 1 & 5 \\
\hline Standards and certifications & $4.23 \pm 1.01$ & 5 & 5 & 2 & 5 \\
\hline Governmental taxes & $3.23 \pm 1.59$ & 3 & 5 & 1 & 5 \\
\hline Governmental subsidies & $3.92 \pm 1.50$ & 5 & 5 & 1 & 5 \\
\hline Rent-seeking behaviour (12) ${ }^{2}$ & $3.83 \pm 1.34$ & 4 & 5 & 2 & 5 \\
\hline Bureaucratic delays & $4.00 \pm 1.22$ & 4 & 5 & 1 & 5 \\
\hline Restrictions on specific plants & $3.85 \pm 1.41$ & 4 & 4 & 1 & 5 \\
\hline \multicolumn{6}{|c|}{ Internal: Financial Capital } \\
\hline Access to capital and credit & $3.92 \pm 1.44$ & 5 & 5 & 1 & 5 \\
\hline Access to insurance & $4.00 \pm 1.29$ & 4 & 5 & 1 & 5 \\
\hline \multicolumn{6}{|c|}{ Internal: Business Management Capacities } \\
\hline Marketing skills & $4.54 \pm 0.66$ & 5 & 5 & 3 & 5 \\
\hline Decentralised management & $2.38 \pm 1.76$ & 1 & 1 & 1 & 5 \\
\hline Role of auditing & $4.31 \pm 1.49$ & 5 & 5 & 1 & 5 \\
\hline \multicolumn{6}{|c|}{ Internal: Clustering/Collaboration with other companies } \\
\hline Importance of being a member of producers' organisations (11) & $4.36 \pm 1.03$ & 5 & 5 & 2 & 5 \\
\hline Importance of sharing knowledge and good practices (10) & $3.90 \pm 1.37$ & 4 & 4 & 1 & 5 \\
\hline Importance of sharing production costs $(2)$ & $4.67 \pm 0.58$ & 5 & 5 & 4 & 5 \\
\hline
\end{tabular}

${ }^{1}$ Scale: 1 = Insignificant, 2 = Slightly significant, 3 = Significant, 4 = Very significant, 5 = Extremely significant.

2 Values in brackets represent the number of respondents (when less than 13).

\subsection{Basic Characteristics of Medicinal Plant Secondary Processing Enterprises}

Very little is known regarding the profiles of medicinal plant secondary processing enterprises-an overview of their basic characteristics is presented in Table 3. Most enterprises are privately owned $(86.1 \%)$ and managed by the owner $(67.1 \%)$, with the CEOs being middle-aged (46.4 $\pm 11.0 \mathrm{yrs})$, well educated $(72.2 \%$ have at least an intermediate education level) males $(93.7 \%)$ with considerable medicinal plant processing experience $(11.8 \pm 7.6 \mathrm{yrs})$ and coming from upper castes $(77.2 \%$ are Brahman, 
Chhetri, or Newar). A slight majority of enterprises (55.7\%) operate on a seasonal basis. Most enterprises stated that they operate with a profit ( $8.9 \%$ at a loss). On average, an enterprise has $6.4 \pm 9.8$ permanent employees and $6.6 \pm 9.2$ temporary employees, both with a range of $0-50$. Generalising employment data per stratum (Appendix A) allows us to estimate a total medicinal plant secondary processing employment of 1131 permanent and 1307 temporary workers (excluding firm owners).

Table 3. A profile of medicinal plant secondary processing enterprises $(n=79)$ in Nepal: basic characteristics of enterprises (A) and CEOs (B).

\begin{tabular}{|c|c|}
\hline A. Enterprise Characteristics & Estimate \\
\hline \multicolumn{2}{|l|}{ Ownership } \\
\hline Privately owned & $86.1 \%$ \\
\hline State owned & $8.9 \%$ \\
\hline Community forest user groups & $2.5 \%$ \\
\hline Multi-purpose cooperative & $2.5 \%$ \\
\hline Permanent employees (no., mean $\pm \mathrm{SD}$, $\min -\max )$ & $6.4 \pm 9.8(0-50)$ \\
\hline Temporary employees (no., mean $\pm \mathrm{SD}$, $\min -\max$ ) & $6.6 \pm 9.2(0-50)$ \\
\hline \multicolumn{2}{|l|}{ Mode of operation } \\
\hline Continuous & $44.3 \%$ \\
\hline Seasonal & $55.7 \%$ \\
\hline \multicolumn{2}{|l|}{ Profitability } \\
\hline Profit & $70.9 \%$ \\
\hline No answer & $16.5 \%$ \\
\hline Loss & $8.9 \%$ \\
\hline Breaking even & $3.8 \%$ \\
\hline B. CEO Characteristics & Estimate \\
\hline Gender (male, female) & $93.7 \%, 6.3 \%$ \\
\hline Age $(\mathrm{yrs}$, mean $\pm \mathrm{SD}, \min -\max )$ & $46.4 \pm 11.0(27-78)$ \\
\hline \multicolumn{2}{|l|}{ Age distribution (yrs) } \\
\hline$\leq 30$ & $3.8 \%$ \\
\hline $31-40$ & $29.1 \%$ \\
\hline $41-50$ & $34.2 \%$ \\
\hline$>50$ & $32.9 \%$ \\
\hline Experience (yrs, mean $\pm \mathrm{SD}$, min-max) & $11.8 \pm 7.6(1-36)$ \\
\hline \multicolumn{2}{|l|}{ Experience distribution (yrs) } \\
\hline$\leq 2$ & $3.8 \%$ \\
\hline $3-5$ & $16.5 \%$ \\
\hline $6-10$ & $30.0 \%$ \\
\hline$>10$ & $41.8 \%$ \\
\hline \multicolumn{2}{|l|}{ Education } \\
\hline Above high school & $72.2 \%$ \\
\hline School Leaving Certificate and equivalent & $15.2 \%$ \\
\hline Lower secondary or primary & $7.6 \%$ \\
\hline Non-formal education, no answer & $5.1 \%$ \\
\hline Castes & \\
\hline Brahman, Chhetri, Newar (higher) & $77.2 \%$ \\
\hline $\begin{array}{c}\text { Sanyasi, Gurung, Muslim, Tharu, Limbu, Magar, Marwadi, Rai, Sherpa, Sonar, Sudhi, } \\
\text { Thakuri (lower) }\end{array}$ & $22.8 \%$ \\
\hline
\end{tabular}

\subsection{Quantifying the Volume and Value of the Annual Demand for Raw Materials}

Medicinal plant secondary processing industries purchased 58 different raw materials and nine intermediate medicinal plant-derived products in 2014-15. A species-level overview is presented in Appendix B. At the national level, the ten species purchased in highest volumes were Gaultheria fragrantissima Wall. (993,414 kg), Juniperus indica Bertol. (654,280 kg), Nardostachys jatamansi (D. Don) DC. $(353,803 \mathrm{~kg})$, Rhododendron anthopogon D. Don $(339,282 \mathrm{~kg})$, Zanthoxylum armatum DC. $(301,209 \mathrm{~kg})$, Artemisia spp. (168,369 kg), Valeriana jatamansi Jones (135,532 kg), Phyllanthus emblica L. (118,100 kg), 
Cinnamomum glaucescens (Buch.-Ham. x Nees) Hand.-Mazz. (100,896 kg), and Acorus calamus L. $(99,676 \mathrm{~kg})$. The total national-level estimated volume was 3679 tonnes with a value of USD 4.02 million (Table 4), of which around $98 \%$ was purchased in Nepal (with 50\% coming from central wholesalers, and the rest similarly split between traders, collectors, and domesticators). Small enterprises dominated the sector, purchasing $76.5 \%$ and $68.7 \%$ of medicinal plant inputs in volume and value terms. Small enterprises in the Kathmandu Valley purchased $49.2 \%$ of the total volume for $22.0 \%$ of the total value, indicating a focus on lower-value raw materials. Small enterprises outside the Kathmandu Valley purchased the most expensive raw materials ( $27.1 \%$ of volume but $46.7 \%$ of value). Figure 2 shows the relative distribution of raw material volumes and values by province. Production was concentrated in Bagmati Province and Province no. 5.

Table 4. Per-stratum and total national-level estimates for volumes and values of (i) purchased medicinal plants as inputs and (ii) end products by the medicinal plant secondary processing sector in Nepal, 2014-15.

\begin{tabular}{ccccccccc}
\hline & \multicolumn{3}{c}{ Purchased Medicinal Plants } & \multicolumn{4}{c}{ End Products } \\
\cline { 2 - 9 } & $\begin{array}{c}\text { Volume } \\
\mathbf{( k g )}\end{array}$ & $\begin{array}{c}\text { Volume } \\
\mathbf{( \% )}\end{array}$ & $\begin{array}{c}\text { Value } \\
\mathbf{( U S D )}\end{array}$ & $\begin{array}{c}\text { Value } \\
\mathbf{( \% )}\end{array}$ & $\begin{array}{c}\text { Volume } \\
\mathbf{( k g )}\end{array}$ & $\begin{array}{c}\text { Volume } \\
\mathbf{( \% )}\end{array}$ & $\begin{array}{c}\text { Value } \\
\text { (USD) }\end{array}$ & $\begin{array}{c}\text { Value } \\
(\%)\end{array}$ \\
\hline Large enterprises & 863,571 & 23.5 & $1,258,268$ & 31.3 & 70,328 & 14.2 & $1,146,635$ & 10.2 \\
Small enterprises & & & & & & & & \\
Kathmandu Valley & $1,818,067$ & 49.4 & 884,457 & 22.0 & 336,973 & 68.2 & $4,518,476$ & 40.2 \\
Other districts & 997,216 & 27.1 & $1,880,161$ & 46.7 & 86,868 & 17.6 & $5,581,175$ & 49.6 \\
\hline Total & $3,678,854$ & 100.0 & $4,022,886$ & 100.0 & 494,169 & 100.0 & $11,246,286$ & 100.0 \\
\hline
\end{tabular}
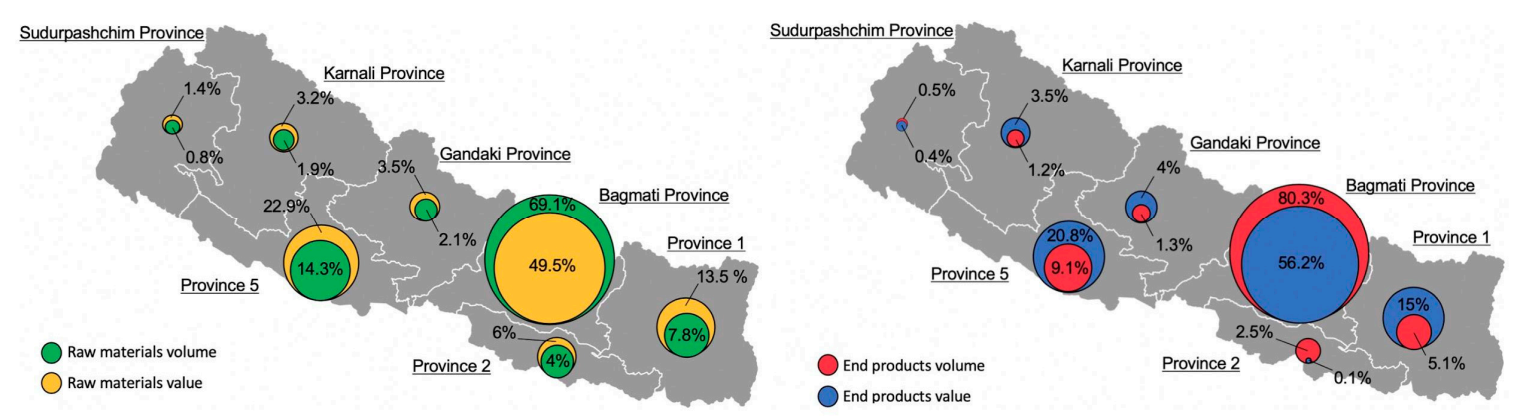

Figure 2. Volume and value shares of purchased raw materials (left) and produced end products (right) by province in the medicinal plant secondary processing industry, Nepal, 2014-15.

\subsection{Quantifying the Volume and Value of the Annual Production of End Products}

Two subsets of medicinal plant secondary processing enterprises provided data on the volume $(n=38)$ and value $(n=20)$ of end products (Table 4$)$ and their main buyer countries. The total estimated production in 2014-15 amounted to 494 tonnes with a value of USD 11.2 million, with small enterprises dominating both in volume $(85.8 \%)$ and value $(89.8 \%)$ terms. The ratio of end product to purchased medicinal plants was much higher for small enterprises (3.0-5.1) than the large enterprises (0.9), indicating both different product portfolios and business models (e.g., the latter may move materials between different production units). Figure 2 graphically shows the shares of end products' volumes and values by province, confirming the concentration in Bagmati Province and Province no. 5.

The enterprises of the first subset $(n=38$; two large and 36 small enterprises located in Kathmandu Valley) reported output volume as Ayurvedic medicine (29.1\%), soap (19.7\%), incense (10.8\%), essential oil $(7.2 \%)$, cosmetics $(7.0 \%)$, food additives $(5.9 \%)$, external applications $(2.6 \%)$, dyes $(2.1 \%)$, and a range of other smaller products (15.4\%). Most sampled companies $(81.0 \%)$ sold their products only on the domestic market in Nepal, while 12.1\% sold in both Nepal and other countries (India, China, Europe, USA), and $6.9 \%$ only exported (again, to India, China, Europe, and the USA). In terms of 
end products and markets, a pattern emerged: the most exported products were the range of smaller products, incense, essential oils, and food additives. Ayurvedic medicines were the products most sold in Nepal.

The second subset of enterprises $(n=20$; five large and four small enterprises located in Kathmandu Valley, and 11 small enterprises located in other districts) produced $31,915 \mathrm{~L}$ and $57,215 \mathrm{~kg}$ of 54 final products, for an estimated total value of USD 2.3 million. They showed that most production is specialised: ten companies (50\%) produced only one product, four $(20 \%)$ three products, two $(10 \%)$ five products, and four (20\%) either 2, 4, 7 or 9 products. Most companies (85.0\%) only sold their products in Nepal, while two (10.0\%) sold to Europe and the USA and one (5.0\%) in both Nepal and India. The pattern is similar to the previous one: essential oils were the main export (to Europe and the USA, but also to India), products for external application found markets in Nepal, Europe, and the USA, while all other products, including Ayurvedic medicines, were solely sold in Nepal. The annual value of the exports of this subset was estimated at USD 0.9 million for 12,252 kg of end products.

These export data from the second subset—even if based on a limited number of enterprises—-were generalised to the total processing enterprise population. In 2014-15, the export of end products was estimated to be $36,303 \mathrm{~kg}$ ( $7.3 \%$ of the total volume of production), for a value of USD 5 million (44.5\% of the total).

\section{Discussion}

This is the first study to dissect the characteristics of medicinal plant processing enterprises at the national level, including actor characteristics and a quantification of the volume and value of annual raw material consumption at the species level. Moreover, the primary data are derived from enterprises themselves, rather than other sources. This enables the below evidence-based discussion in relation to the wider literature as well as how to progress with integrating commercial medicinal plants into the transition to the bioeconomy in low-income countries.

\subsection{The Emergence of the Nepalese Medicinal Plant Secondary Processing Sector}

Rising domestic demand for consumer products containing medicinal plants is the factor driving the increase in the number of medicinal plant secondary processing enterprises in Nepal, up from fewer than 20 in the late 1990s to several hundred today-somewhere between 233-325 enterprises according to [31]. This rising domestic demand has been noted in a few studies [1,58,59]. Private actors are pulled into the industry in response to opportunities and market signals; the emergence of the sector was thus not a result of public policy measures aimed at the medicinal plant production network-for an overview of such policies, e.g., the government's Herbs and Non-Timber Forest Product Development Policy from 2004, see [12].

The emergence of the medicinal plant secondary processing sector in Nepal is part of a wider regional pattern with two important components:

1. Consumers in India and China are increasingly consuming medicinal plant products. This has been noted as a demand driver in empirical trade studies in Nepal [36], as well as in sector-related studies in India [11,60] and China [21,61,62].

2. Traditional medicine systems are increasingly commercialised, including mass production and marketing, and hence more widely available to consumers. While the change in Tibet took its point of departure from legislative requirements [20], the change in Nepal is purely demand-driven, indicating several pathways towards industrialisation and growth in traditional medicine systems.

These regional patterns themselves appear to be part of a wider global trend towards higher medicinal plant consumption, e.g., in [1] a tripling of the global medicinal plant trade value was noted in the past 15 years, with rising prices indicating that demand is outstripping a relatively inelastic supply. The same report also referred to changing population demographics (more older people), 
the importance of rising Asian middle-class incomes, urbanisation, medical breakthroughs, and higher awareness of health issues as likely to lead to long-term medicinal plant industry growth.

\subsection{The Economic Importance of the Nepalese Medicinal Plant Secondary Processing Sector}

The medicinal plant production network in Nepal is characterised by the large-scale export of air-dried products $[27,36]$ and, as found in this paper, limited albeit growing secondary processing aimed at the domestic market, i.e., catering to an existing and growing market. As such, Nepal is mainly a regional supplier of raw materials to industries in India and China. This lack of realisation of in-country economic potential is also seen with other natural resources in Nepal: in [63], it was found that local incomes from wood products from community forestry could increase up to tenfold if households were allowed to sell sustainably harvested products on the markets. However, the large share of Ayurvedic products (29.1\% of total production) indicates, as also noted in [1], an ability to compete with imported traditional medicine products.

A notable feature of the studied enterprises is that they tend to focus on relatively few species; this is a common characteristic of smaller enterprises processing non-timber forest products [18]. Other similarities are a reliance on a large number of small-scale producers and a lack of attention to product quality issues, e.g., as demonstrated by the lack of laboratory facilities.

The annual industry consumption of 3679 tonnes of medicinal plants is low compared to the annual production, estimated at 7000 to 27,000 tonnes [27]. The scope for increasing domestic processing is substantial and would require access to export markets. Raw materials are almost exclusively $(97.8 \%)$ from Nepal, with distinct production and processing areas (Figure 2), and most commonly obtained (Appendix B) from central wholesalers (50.0\%), but also with some purchases directly from traders $(16.5 \%)$, collectors $(16.9 \%)$, or from their own cultivation $(13.9 \%)$, reflecting a web of multi-level relations in the medicinal plant production network and different (still unknown) business models. While direct employment is limited to a few thousand jobs, this is in addition to the hundreds of thousands of people involved in harvesting and trade [35]. Also, it should be noted that the average number of 6.4 permanent jobs per medicinal plant secondary processing enterprise is higher than the average number for enterprises in Nepal and Kathmandu, 3.7 and 4.6 respectively [64].

Even in the current setup, with limited domestic processing and most enterprises (81\%) focusing exclusively on the domestic market, the production network of medicinal plants is of national significance with an annual production of 494 tonnes of consumer products valued at USD 11.2 million, out of which the export of 36.3 tonnes of end products ( $7.3 \%$ of total production) generated a value of USD 5 million ( $44.5 \%$ of total value). This is a substantial share of the "medicaments" (including Ayurvedic products) export from Nepal valued at around USD 7.5 million in 2015, even if it is a fraction of Indian medicinal plant export (USD 290 million in 2017) or essential oil export from France, which includes extracts from imported Nepalese plants (USD 399 million in 2017) [1]. In addition to public health services and tax revenues, the export contribution (Nepal runs a large negative balance of payments), and jobs, there appears to be a large untapped potential for expanding the sector.

\subsection{The Potential of the Nepalese Medicinal Plant Secondary Processing Sector to Contribute to the Bioeconomy}

As with other low-income countries, Nepal needs to develop its domestic economy to reach middle-income levels [65]. Nepal aims to achieve "lower-middle-income country" status by 2030 [66], an ambition that can only be realised if the country escapes its current low-growth trap [67]: the ongoing large-scale outmigration follows from lack of employment opportunities at home while simultaneously decreasing the pressure for creating new in-country jobs and improving public service delivery. The medicinal plant secondary processing sector can contribute to reaching this national goal - the development of the industry has already been identified as a government priority [68]—while contributing to a transition towards a bioeconomy (emphasising the simultaneous achievement of economic growth and environmental sustainability). Three key questions need to be answered: 
1. How can Nepal transform from being a supplier of raw materials and producer of lower-value domestic consumer products to integrating into the global economy as an exporter of higher-value products? This transformation requires solutions to the obstacles identified above: export barriers, technology and service barriers, labour challenges, socio-economic and political instability, and the cumbersome and inefficient bureaucracy. Many of these obstacles are also faced by other natural product processing enterprises elsewhere, e.g., non-timber forest product-processing small enterprises in Africa struggle with developing upgrading and becoming part of traceability schemes [18]. While instability is a generic issue cutting across all sectors, as is the general difficulty of doing business (e.g., Nepal ranks as 135 out of 190 countries in terms of the ease of starting a business, [69]), the other challenges can, at least in theory, be addressed through initiatives aimed at the medicinal plant production network. Rather than trying to outguess the markets, the emphasis should be on establishing generic support functions and interventions that can then be accessed by a variety of enterprises. Paramount to accessing export markets is meeting established standards, such as international standards for phytosanitary measures and compliance with WHO-GMP standards in the case of traditional medicine products. This could be supported through funding to establish accredited laboratories and support for achieving certifications. This could have positive knock-on effects, e.g., such infrastructure could induce enterprise investment in improved technology that would increase competitiveness, and storage facilities that would allow more efficient trade throughout the year $[18,19]$. Labour shortage is common throughout Nepal, e.g., almost half of all households have at least one family member working abroad or a returnee [56] and important high-altitude medicinal plant production areas are being depopulated [70]. Attracting labour into medicinal plant secondary processing enterprises seems presently to be a matter of salaries; more competitive export-oriented enterprises would be better positioned to attract both skilled and unskilled labour. Cooperation between processing enterprises through associations and cooperatives could improve the sharing of skills and knowledge and increase bargaining power, e.g., with traders and the government $[19,71]$. The inefficient bureaucracy is not an issue that is easily addressed; recommendations to deal with the associated challenges have been made in a number of policies (that can be read as a long string of well-intentioned interventions), including the Herbs and Non-Timber Forest Product Development Policy from 2004. Rather than repeat past ineffective recommendations, there is a need to understand the political ecology of the medicinal plant production network in Nepal, to arrive at feasible solutions (at both national and provincial levels). Work has progressed on this in the wider forest sector [72,73] and forms a solid starting point for medicinal plant related progress. The importance of a supportive institutional framework is general to the development of competitive natural product enterprises regardless of location $[16,19]$. This would also serve to prevent repeats of the 2018 jatamansi trade ban and to increase the competitiveness of the sector, e.g., through less rent-seeking and clearer legislation on who can tax medicinal plant trade and processing. To provide a common agreement on goals and a consolidated effort to implement interventions, a theory of change should be developed.

2. How can supplies be sustained in the face of increasing demands (whether to support ongoing raw material export or the development of the domestic industry)? Maintaining or developing an abundant resource base is essential for natural product processing industries [16,18]. Even if there is a lack of studies documenting unsustainable harvests [12] - such studies are resource consuming - there is widespread concern that a number of species may currently be overharvested (e.g., Paris polyphylla Sm., Nardostachys jatamansi (D. Don) DC., Neopicrorhiza scrophulariiflora (Pennell) D. Y. Hong, and Zanthoxylum armatum DC.) $[4,44,58,74,75]$. Given the currently available funding for medicinal plant-related research, there is no way to establish species-level sustainable harvest estimates for the 300 species in trade [26]. However, combining existing information on trade and vulnerability will allow the short-listing of species to focus on, e.g., in [27] it was shown that the medicinal plant trade focuses on few species, in both volume and value terms, 
while in [26] there is a recent conservation assessment. In addition to estimating species-level sustainable harvest estimates for highly traded and vulnerable species, it is important to improve our understanding of the political ecology of the bioeconomy of which the medicinal plant sector is a part. Studies from community forestry indicate that existing official harvest quotas, including those for medicinal plants from district level five-year plans, should be treated with scepticism [72,73] as they serve to satisfy bureaucracy rather than ensure sustainable harvests. Further understanding of the political ecology would reinforce sector understanding and thus underpin the formulation of feasible public policy interventions to address the identified obstacles to developing sustainable secondary medicinal plant processing in Nepal.

3. Can commercial medicinal plants support a transition to the bioeconomy? Greenhouse gasses affect the earth's climate [76] and actions are required to develop affordable and efficient transition pathways to low-carbon economies [65]. Ways to decarbonise include reducing the amount of $\mathrm{CO}_{2}$ returned to the atmosphere through the enhanced use of wood and other plant products in materials. This has led to a biotechnological dominance in the young research field of bioeconomy, with most published studies focused on the EU [45,77]. This dominant biotechnological approach is decoupled from sustainability concerns [45] and its emphasis on natural science, biotechnology, and patents makes it less relevant to low-income countries. There is a need to develop a bioeconomy of renewable resources in low-income countries. While this is beyond the scope of this paper, the presented case provides a rich starting point for providing input to such a school of thought-there is a huge and growing trade, ample opportunities for expanding processing (and reducing the export of raw materials), and a specific list of obstacles to be addressed from a bioeconomic starting point.

Even though commercial medicinal plant trade is centuries old in Nepal [41], secondary processing is new and faces many challenges. Productive avenues of future research would be (i) increasing the quality of raw materials, e.g., understanding variation across sites, timing, plant age, drying and storage; (ii) establishing species-level sustainable harvest guidelines, (iii) promoting new modes of production, e.g., by coupling enterprises to organisations of local producers; (iv) developing a theory of change that facilitates realistic interventions in the sector, including the dismantling of obstacles impeding successful enterprise development, and (v) establishing a bioeconomic approach relevant to renewable natural resources in low-income countries.

\section{Conclusions}

Medicinal plants are a key asset of Nepal. With better management of the sector, this asset can contribute to increased prosperity-demand for consumer products containing medicinal plants already exists. Domestic demand was the starting point for the commercialisation and growth of the medicinal plant secondary processing sector in Nepal, following regional and global trends of higher consumption of traditional medicine products. However, Nepal is a supplier of raw materials to mainly India and China and a producer of lower-value domestic consumer products rather than an exporter of higher-value products. To make this transition, and benefit from a potential manifold increase in exports, sustained and consolidated efforts must be made to address the obstacles hindering enterprise operations and expansion. This includes simplifying bureaucratic procedures, creating stable and supportive legislation, establishing missing infrastructure such as for product quality testing and supporting certification processes, and improving access to processing technology and labour. These limitations are found for many non-timber forest product enterprises in the Global South. What is missing, across products and countries, are interventions based on actor agreements on explicit pathways that promote sustainable economic growth while conserving the resource base. Such pathways can be developed as part of a theory of change that can then form the basis for establishing national bioeconomy strategies relevant to renewable natural resources in low-income countries. 
Supplementary Materials: The following are available online at http://www.mdpi.com/2071-1050/12/14/5575/s1, Table S1: Medicinal plant secondary processor perception survey.

Author Contributions: Conceptualisation, methodology, and validation, all; formal analysis, F.C., J.M.-M., M.F.U.; investigation, F.C., J.M.-M., M.F.U.; writing-original draft preparation, F.C., J.M.-M., M.F.U.; writing-review and editing, C.S.-H.; visualisation, F.C., J.M.-M., M.F.U.; supervision, C.S.-H.; funding acquisition, C.S.-H. All authors have read and agreed to the published version of the manuscript.

Funding: This research was funded by the Research Committee for Development Research (FFU) of the Danish Ministry of Foreign Affairs, Grant No. 13-07KU.

Acknowledgments: The authors thank all the people at the medicinal plant enterprises for their time and valuable information; the representatives of the Ayurvedic Medicine Producers Association of Nepal (AMPAN), the Herbal Entrepreneur Association Nepal (HEAN), and the Nepal Herbs and Herbal Products Association (NEHHPA) for their inputs; Dipesh Pyakurel for his assistance in contacting informants and companies; Arjun Chapagain and Gandhiv Kafle for their contributions to compiling the enterprise population list and collecting data; and Abhoy Kumar Das for administrative support.

Conflicts of Interest: The authors declare no conflict of interest. The funders had no role in the design of the study; in the collection, analyses, or interpretation of data; in the writing of the manuscript, or in the decision to publish the results.

\section{Appendix A}

Table A1. Medicinal plant secondary processing: average numbers of permanent and temporary employees by stratum and in total.

\begin{tabular}{ccc}
\hline Stratum/Employees & Permanent Employees (no.) & Temporary Employees (no.) \\
\hline Large enterprises & & \\
average \pm SD & $24.9 \pm 16.8$ & $6.1 \pm 7.7$ \\
generalisation & 248.8 & 61.3 \\
Small enterprises_Kathmandu Valley & $5.1 \pm 4.2$ & $9.3 \pm 10.1$ \\
average \pm SD & 468.3 & 845.6 \\
generalisation & $3.1 \pm 7.5$ & $3.0 \pm 7.0$ \\
Small enterprises—other districts & 413.6 & 400.4 \\
average \pm SD & 1130.7 & 1307.3 \\
generalisation & &
\end{tabular}




\section{Appendix B}

Table A2. National-level value-ordered overview of medicinal plant secondary processing enterprises $(\mathrm{n}=79)$ : the volume and value of medicinal plant products purchased, 2014-15, Nepal.

\begin{tabular}{|c|c|c|c|c|c|c|c|c|c|c|c|c|c|c|c|c|}
\hline \multirow[b]{2}{*}{ Common Trade Name $^{2}$} & \multirow[b]{2}{*}{ Species Scientific Name } & \multirow[b]{2}{*}{$\begin{array}{c}\text { Volume } \\
\text { Purchased } \\
\text { (kg) }\end{array}$} & \multirow[b]{2}{*}{$\begin{array}{c}\text { Estimated } \\
\text { Purchased Volume } \\
\text { at National Level } \\
(\mathrm{kg})\end{array}$} & \multirow[b]{2}{*}{$\begin{array}{c}\% \\
\begin{array}{c}\% \\
\text { Purchased } \\
\text { in Nepal }\end{array}\end{array}$} & \multirow[b]{2}{*}{$\begin{array}{l}\text { Average } \\
\text { Price/kg } \\
\text { (NPR) }\end{array}$} & \multirow[b]{2}{*}{$\begin{array}{c}\text { Average } \\
\text { Price } \\
\text { Standard } \\
\text { Deviation }\end{array}$} & \multirow[b]{2}{*}{$\begin{array}{c}\text { Estimated } \\
\text { Accumulated } \\
\text { Value at National } \\
\text { Level (USD) }\end{array}$} & \multicolumn{9}{|c|}{ Raw Materials Purchased from ${ }^{1}(\%)$} \\
\hline & & & & & & & & $\begin{array}{l}\text { Collec- } \\
\text { Tors }\end{array}$ & Domesti-cators & $\begin{array}{l}\text { Local } \\
\text { Traders }\end{array}$ & $\begin{array}{c}\text { Sub-local } \\
\text { Permanent } \\
\text { Traders }\end{array}$ & $\begin{array}{c}\text { Local } \\
\text { Specialist } \\
\text { Traders }\end{array}$ & $\begin{array}{c}\text { Local } \\
\text { Generalist } \\
\text { Traders }\end{array}$ & $\begin{array}{c}\text { Central } \\
\text { Whole-salers }\end{array}$ & $\begin{array}{c}\text { Regional } \\
\text { Whole- } \\
\text { salers }\end{array}$ & $\begin{array}{l}\text { Own } \\
\text { Produc- } \\
\text { tion }\end{array}$ \\
\hline Jatamansi & Nardostachys jatamansi & 168,318 & 353,803 & 100.0 & 3844.0 & $11,403.3$ & $2,151,574$ & 21.2 & 0.0 & 0.0 & 0.0 & 5.8 & 6.2 & 66.9 & 0.0 & 0.0 \\
\hline Timur & Zanthoxylum armatum & 143,297 & 301,209 & 100.0 & 220.7 & 82.7 & 267,544 & 6.0 & 13.1 & 0.0 & 0.0 & 0.0 & 9.5 & 61.9 & 0.0 & 9.5 \\
\hline Sugandhawal (samayo) & Valeriana jatamansi & 64,478 & 135,532 & 100.0 & 220.9 & 87.9 & 240,933 & 23.5 & 0.0 & 0.0 & 0.0 & 5.9 & 15.3 & 55.3 & 0.0 & 0.0 \\
\hline Silajeet & A rock exudate & 6797 & 14,287 & 100.0 & 1423.1 & 1508.8 & 194,941 & 0.0 & 0.0 & 12.5 & 0.0 & 0.0 & 0.0 & 87.5 & 0.0 & 0.0 \\
\hline Sunpati & Rhododendron anthopogon & 161,410 & 339,282 & 100.0 & 32.5 & 40.3 & 120,775 & 58.3 & 0.0 & 0.0 & 0.0 & 0.0 & 0.0 & 41.7 & 0.0 & 0.0 \\
\hline $\begin{array}{l}\text { Sugandhakokila } \\
\text { (sugandhkokila) }\end{array}$ & Cinnamomum glaucescens & 48,000 & 100,896 & 100.0 & 93.3 & 5.8 & 96,528 & 16.7 & 16.7 & 0.0 & 0.0 & 0.0 & 33.3 & 33.3 & 0.0 & 0.0 \\
\hline Kutki (katuki) & Neopicrorhiza scrophularififora & 2613 & 5493 & 100.0 & 1389.1 & 227.8 & 80,370 & 7.7 & 0.0 & 0.0 & 0.0 & 0.0 & 7.7 & 84.6 & 0.0 & 0.0 \\
\hline Amala & Phyllanthus emblica & 56,185 & 118,100 & 98.4 & 68.1 & 27.1 & 78,270 & 13.0 & 4.2 & 0.0 & 1.9 & 1.6 & 4.1 & 62.7 & 0.6 & 11.8 \\
\hline Kurilo (satawari) & Asparagus spp. & 9957 & 20,930 & 100.0 & 254.3 & 65.9 & 58,587 & 8.2 & 0.9 & 0.0 & 4.5 & 0.0 & 0.0 & 72.7 & 0.0 & 13.6 \\
\hline Dhupi (kalo) & Juniperus indica & 311,267 & 654,280 & 100.0 & 251.9 & 866.5 & 54,122 & 43.8 & 0.0 & 0.0 & 0.0 & 0.0 & 0.0 & 56.3 & 0.0 & 0.0 \\
\hline Bojho (bhojo) & Acorus calamus & 47,420 & 99,676 & 100.0 & 84.0 & 30.8 & 52,485 & 10.0 & 10.0 & 0.0 & 0.0 & 5.0 & 0.0 & 65.0 & 0.0 & 10.0 \\
\hline $\begin{array}{l}\text { Pipla } \\
\end{array}$ & Piper longum & 6044 & 12,704 & 100.0 & 520.8 & 427.0 & 50,227 & 5.0 & 0.0 & 0.0 & 5.0 & 0.0 & 15.0 & 75.0 & 0.0 & 0.0 \\
\hline Other & & 11,395 & 23,952 & 100.0 & 328.3 & 575.5 & 50,080 & 0.0 & 0.0 & 0.0 & 0.0 & 0.0 & 16.7 & 83.3 & 0.0 & 0.0 \\
\hline Harro & Terminalia chebula & 36,409 & 76,531 & 94.8 & 58.8 & 21.2 & 49,164 & 19.9 & 2.7 & 0.0 & 0.0 & 2.3 & 7.4 & 57.8 & 0.6 & 9.3 \\
\hline Dhasingre (machhino) & Gaultheria fragrantissima & 472,606 & 993,414 & 100.0 & 403.8 & 1198.6 & 48,340 & 72.7 & 0.0 & 9.1 & 0.0 & 0.0 & 0.0 & 18.2 & 0.0 & 0.0 \\
\hline Chiraito (tite) & Swertia chirayita & 3456 & 7264 & 100.0 & 492.1 & 95.7 & 38,328 & 5.6 & 0.0 & 0.0 & 0.0 & 0.0 & 5.6 & 88.9 & 0.0 & 0.0 \\
\hline Barro & Terminalia bellirica & 32,443 & 68,195 & 95.2 & 50.2 & 18.1 & 37,506 & 11.9 & 5.0 & 0.0 & 0.0 & 2.2 & 7.1 & 57.5 & 0.9 & 15.5 \\
\hline Chiuri & Diploknema butyracea & 5670 & 11,918 & 100.0 & 281.5 & 50.1 & 34,901 & 0.0 & 7.7 & 7.7 & 0.0 & 0.0 & 0.0 & 84.6 & 0.0 & 0.0 \\
\hline Satuwa (seto) & Paris polyphylla & 200 & 420 & 100.0 & 5900.0 & 1140.2 & 24,346 & 0.0 & 0.0 & 0.0 & 0.0 & 0.0 & 0.0 & 100.0 & 0.0 & 0.0 \\
\hline Titepati & Artemisa spp. & 80,100 & 168,369 & 100.0 & 16.4 & 24.4 & 21,464 & 70.0 & 10.0 & 0.0 & 0.0 & 0.0 & 0.0 & 20.0 & 0.0 & 0.0 \\
\hline Nirmasi (nirmansi) & Delphinium denudatum & 121 & 254 & 100.0 & 5675.0 & 236.3 & 14,386 & 0.0 & 0.0 & 0.0 & 0.0 & 0.0 & 0.0 & 100.0 & 0.0 & 0.0 \\
\hline Dalchini & Cinnamomum tamala & 6395 & 13,442 & 100.0 & $\begin{array}{l}100.0 \\
\end{array}$ & 38.6 & 13,237 & 0.0 & 0.0 & 0.0 & 0.0 & 0.0 & 8.3 & 87.5 & 0.0 & 4.2 \\
\hline Tejpat & Cinnamomum tamala & 15,131 & 31,805 & 100.0 & 60.2 & 16.4 & 12,264 & 8.2 & 5.5 & 0.0 & 0.0 & 0.0 & 4.5 & 77.3 & 0.0 & 4.5 \\
\hline Majitho & Rubia manjith & 3502 & 7361 & $\begin{array}{l}100.0 \\
\end{array}$ & 121.0 & 52.6 & 10,450 & 0.0 & 0.0 & 0.0 & 0.0 & 0.0 & 0.0 & 100.0 & 0.0 & 0.0 \\
\hline Kaulo & Machilus spp. & 5600 & 11,771 & 100.0 & 77.0 & 21.7 & 8387 & 5.0 & 5.0 & 0.0 & 0.0 & 0.0 & 10.0 & 80.0 & 0.0 & 0.0 \\
\hline Rittha & Sapindus mukorossi & 14,339 & 30,140 & 100.0 & 28.3 & 7.5 & 7862 & 8.3 & 0.0 & 0.0 & 0.0 & 0.0 & 0.0 & 91.7 & 0.0 & 0.0 \\
\hline Gurjo (guduchi) & Tinospora spp. & 8396 & 17,648 & 100.0 & 31.7 & 18.5 & 5760 & 16.7 & 0.0 & 0.0 & 0.0 & 8.3 & 0.0 & 33.3 & 0.0 & 41.7 \\
\hline Kauso & Mucuna pruriens & 650 & 1366 & 33.0 & 400.0 & - & 5577 & 25.0 & 25.0 & 0.0 & 0.0 & 0.0 & 0.0 & 0.0 & 50.0 & 0.0 \\
\hline Rudraksha (rudrakshya) & Elaeocarpus angustifolius & 141 & 296 & $\begin{array}{l}100.0 \\
\end{array}$ & 1500.0 & - & 4536 & 0.0 & 0.0 & 0.0 & 0.0 & 100.0 & 0.0 & 0.0 & 0.0 & 0.0 \\
\hline Sarpagandha & Rauvolfia serpentina & 965 & 2028 & 100.0 & 766.7 & 1068.1 & 3699 & 33.3 & 0.0 & 0.0 & 0.0 & 0.0 & 0.0 & 33.3 & 0.0 & 33.3 \\
\hline $\begin{array}{l}\text { Seto musli } \\
\end{array}$ & Chlorophytum spp. & 75 & 158 & 100.0 & 1500.0 & - & 2414 & 0.0 & 0.0 & 0.0 & 0.0 & 0.0 & 0.0 & 100.0 & 0.0 & 0.0 \\
\hline Sikakai & Senegalia rugata & 1170 & 2459 & $\begin{array}{l}100.0 \\
\end{array}$ & 80.0 & 75.1 & 1790 & 0.0 & 0.0 & 0.0 & 0.0 & 0.0 & 0.0 & 100.0 & 0.0 & 0.0 \\
\hline Chabo & Piper chaba & 284 & 597 & 100.0 & 246.7 & 219.4 & 1546 & 33.3 & 0.0 & 0.0 & 0.0 & 0.0 & 0.0 & 66.7 & 0.0 & 0.0 \\
\hline Pakhanved & Bergenia spp. & 840 & 1766 & 92.0 & 58.5 & 23.3 & 1322 & 0.0 & 0.0 & 0.0 & 0.0 & 0.0 & 0.0 & 70.0 & 0.0 & 30.0 \\
\hline Chutro & Berberis spp. & 1351 & 2840 & 100.0 & 32.0 & 13.6 & 1186 & 14.3 & 0.0 & 0.0 & 0.0 & 0.0 & 0.0 & 85.7 & 0.0 & 0.0 \\
\hline
\end{tabular}


Table A2. Cont.

\begin{tabular}{|c|c|c|c|c|c|c|c|c|c|c|c|c|c|c|c|c|}
\hline & & & & & & & & \multicolumn{9}{|c|}{ Raw Materials Purchased from ${ }^{1}(\%)$} \\
\hline Common Trade Name $^{2}$ & Species Scientific Name & $\begin{array}{c}\text { Volume } \\
\text { Purchased } \\
(\mathrm{kg})\end{array}$ & $\begin{array}{l}\text { Estimated } \\
\begin{array}{l}\text { Purchased Volume } \\
\text { at National Level } \\
\text { (kg) }\end{array}\end{array}$ & $\begin{array}{c}\% \\
\begin{array}{c}\% \\
\text { Purchased } \\
\text { in Nepal }\end{array}\end{array}$ & $\begin{array}{l}\text { Average } \\
\text { Price/kg } \\
\text { (NPR) }\end{array}$ & $\begin{array}{l}\text { Average } \\
\text { Price } \\
\text { Standard } \\
\text { Deviation }\end{array}$ & $\begin{array}{c}\text { Estimated } \\
\text { Accumulated } \\
\text { Value at National } \\
\text { Level (USD) }\end{array}$ & $\begin{array}{l}\text { Collec- } \\
\text { Tors }\end{array}$ & Domesti-cators & $\begin{array}{l}\text { Local } \\
\text { Traders }\end{array}$ & $\begin{array}{l}\text { Sub-local } \\
\text { Permanent } \\
\text { Traders }\end{array}$ & $\begin{array}{c}\text { Local } \\
\text { Specialist } \\
\text { Traders }\end{array}$ & $\begin{array}{c}\text { Local } \\
\text { Generalist } \\
\text { Traders }\end{array}$ & $\begin{array}{c}\text { Central } \\
\text { Whole-salers }\end{array}$ & $\begin{array}{l}\text { Regional } \\
\text { Whole- } \\
\text { salers }\end{array}$ & $\begin{array}{l}\text { Own } \\
\text { Produc- } \\
\text { tion }\end{array}$ \\
\hline Jiwanti & Dendrobium spp. & 35 & 74 & 100.0 & 1400.0 & - & 1050 & 100.0 & 0.0 & 0.0 & 0.0 & 0.0 & 0.0 & 0.0 & 0.0 & 0.0 \\
\hline Bel & Aegle marmelos & 250 & 525 & 100.0 & 120.0 & - & 644 & 0.0 & 0.0 & 0.0 & 0.0 & 0.0 & 0.0 & 0.0 & 0.0 & 100.0 \\
\hline Guchi chyau & Morchella spp. & 2 & 4 & 100.0 & $12,000.0$ & - & 514 & 0.0 & 0.0 & 0.0 & 0.0 & 0.0 & 0.0 & 100.0 & 0.0 & 0.0 \\
\hline Rato chyau & Laetiporus sulphureus & 20,000 & 42,040 & 100.0 & 1.0 & - & 428 & 0.0 & 0.0 & 0.0 & 0.0 & 0.0 & 0.0 & 0.0 & 0.0 & 100.0 \\
\hline Nisodh & Operculina turpethum & 40 & 84 & 100.0 & 480.0 & - & 411 & 0.0 & 0.0 & 0.0 & 0.0 & 0.0 & 100.0 & 0.0 & 0.0 & 0.0 \\
\hline Ghodtapre (brahmi) & Centella asiatica & 100 & 210 & 100.0 & 150.0 & - & 321 & 0.0 & 0.0 & 0.0 & 0.0 & 0.0 & 0.0 & 100.0 & 0.0 & 0.0 \\
\hline Padamchal roots & Rheum spp. & 110 & 231 & 100.0 & 117.0 & 46.6 & 283 & 0.0 & 0.0 & 0.0 & 0.0 & 0.0 & 0.0 & 100.0 & 0.0 & 0.0 \\
\hline Attis & Delphinium himalayae & 100 & 210 & 100.0 & 1200.0 & - & 257 & 0.0 & 0.0 & 0.0 & 0.0 & 0.0 & 0.0 & 100.0 & 0.0 & 0.0 \\
\hline Arjun & Terminalia arjuna & 40 & 84 & 100.0 & 260.0 & - & 224 & 0.0 & 0.0 & 0.0 & 0.0 & 0.0 & 100.0 & 0.0 & 0.0 & 0.0 \\
\hline Kukurdyane & Smilax spp. & 15 & 32 & 100.0 & 550.0 & - & 178 & 0.0 & 0.0 & 0.0 & 0.0 & 0.0 & 100.0 & 0.0 & 0.0 & 0.0 \\
\hline Tulsi & Ocimum tenuiforum & 150 & 315 & 100.0 & 40.5 & - & 174 & 0.0 & 0.0 & 0.0 & 0.0 & 0.0 & 0.0 & 50.0 & 0.0 & 50.0 \\
\hline Aloe vera & Aloe vera & 700 & 1471 & 100.0 & 10.0 & - & 149 & 95.0 & 5.0 & 0.0 & 0.0 & 0.0 & 0.0 & 0.0 & 0.0 & 0.0 \\
\hline Jamuno (jamun beej) & Syzygium cumini & 100 & 210 & 100.0 & 35.0 & - & 75 & 100.0 & 0.0 & 0.0 & 0.0 & 0.0 & 0.0 & 0.0 & 0.0 & 0.0 \\
\hline Bhringiraj (bhringaraj) & Eclipta prostrata & 100 & 210 & 100.0 & 25.0 & - & 53 & 100.0 & 0.0 & 0.0 & 0.0 & 0.0 & 0.0 & 0.0 & 0.0 & 0.0 \\
\hline Panchaaule & Dactylorhiza hatagirea & 33 & 69 & 36.0 & 36.0 & - & 26 & 100.0 & 0.0 & 0.0 & 0.0 & 0.0 & 0.0 & 0.0 & 0.0 & 0.0 \\
\hline Vyakur & Dioscorea deltoidea & 25 & 53 & 100.0 & 35.0 & - & 18 & 100.0 & 0.0 & 0.0 & 0.0 & 0.0 & 0.0 & 0.0 & 0.0 & 0.0 \\
\hline Asuro (ashuro) & Justicia adhatoda & 63 & 132 & 100.0 & 1.0 & - & 2 & 0.0 & 0.0 & 0.0 & 0.0 & 100.0 & 0.0 & 0.0 & 0.0 & 0.0 \\
\hline Yarsagumba (yartsagunbu) & Ophiocordyceps sinensis & 8 & 17 & 100.0 & 5.7 & 8.1 & 0 & 0.0 & 0.0 & 0.0 & 0.0 & 0.0 & 0.0 & 100.0 & 0.0 & 0.0 \\
\hline Tope jhar & & 3 & 6 & 100.0 & 0.0 & - & 0 & 0.0 & 0.0 & 0.0 & 0.0 & 0.0 & 0.0 & 0.0 & 0.0 & 100.0 \\
\hline Thulo begar & Astilbe rivularis & 20 & 42 & 100.0 & 0.0 & - & 0 & 0.0 & 0.0 & 0.0 & 0.0 & 0.0 & 0.0 & 0.0 & 0.0 & 100.0 \\
\hline Sikari lahara & Periploca calophylla & 20 & 42 & 100.0 & 0.0 & - & 0 & 0.0 & 0.0 & 0.0 & 0.0 & 0.0 & 0.0 & 0.0 & 0.0 & 100.0 \\
\hline Kukhurekath & & 15 & 32 & 100.0 & 0.0 & - & 0 & 0.0 & 0.0 & 0.0 & 0.0 & 0.0 & 0.0 & 0.0 & 0.0 & 100.0 \\
\hline Chini lahara (chini jhar) & Scoparia dulcis & 3 & 6 & 100.0 & 0.0 & - & 0 & 0.0 & 0.0 & 0.0 & 0.0 & 0.0 & 0.0 & 0.0 & 0.0 & 100.0 \\
\hline \multicolumn{2}{|c|}{ Raw materials' subtotals: } & $1,748,957$ & $3,676,292$ & & & & $3,849,707$ & & & & & & & & & \\
\hline Timur oil & Zanthoxylum armatum & 146 & 307 & 100.0 & $29,000.0$ & - & 90,824 & 0.0 & 0.0 & 0.0 & 0.0 & 100.0 & 0.0 & 0.0 & 0.0 & 0.0 \\
\hline Jatamansi oil & Nardostachys jatamansi & 30 & 63 & 100.0 & $46,500.0$ & - & 30,246 & 0.0 & 0.0 & 0.0 & 0.0 & 0.0 & 0.0 & 100.0 & 0.0 & 0.0 \\
\hline Dhasingre oil & Gaultheria fragrantissima & 400 & 841 & 100.0 & 2000.0 & - & 17,160 & 0.0 & 0.0 & 0.0 & 0.0 & 100.0 & 0.0 & 0.0 & 0.0 & 0.0 \\
\hline Tejpat oil & Cinnamomum tamala & 90 & 189 & 100.0 & 5720.0 & - & 11,043 & 0.0 & 0.0 & 0.0 & 0.0 & 100.0 & 0.0 & 0.0 & 0.0 & 0.0 \\
\hline Juniper oil & Juniperus indica & 70 & 147 & 100.0 & 4500.0 & - & 6757 & 0.0 & 0.0 & 0.0 & 0.0 & 0.0 & 0.0 & 100.0 & 0.0 & 0.0 \\
\hline Sugandahkokila oil & Cinnamomum glaucescens & 100 & 210 & 100.0 & 3000.0 & - & 6434 & 0.0 & 0.0 & 0.0 & 0.0 & 0.0 & 0.0 & 100.0 & 0.0 & 0.0 \\
\hline Sunpati oil & Rhododendron anthopogon & 100 & 210 & 100.0 & 2200.0 & - & 4718 & 0.0 & 0.0 & 0.0 & 0.0 & 0.0 & 0.0 & 100.0 & 0.0 & 0.0 \\
\hline Dhupi oil & Juniperus spp. & 33 & 69 & 100.0 & 6500.0 & - & 4602 & 0.0 & 0.0 & 0.0 & 0.0 & 100.0 & 0.0 & 0.0 & 0.0 & 0.0 \\
\hline Jatamansi marc & Nardostachys jatamansi & 250 & 525 & 100.0 & 275.0 & - & 1395 & 0.0 & 0.0 & 0.0 & 0.0 & 0.0 & 0.0 & 100.0 & 0.0 & 0.0 \\
\hline \multirow{3}{*}{\multicolumn{2}{|c|}{$\begin{array}{l}\text { Intermediate products' subtotals: } \\
\end{array}$}} & 1219 & 2562 & & & & 173,179 & & & & & & & & & \\
\hline & & $\begin{array}{c}\text { Total } \\
\text { volume } \\
\text { purchased } \\
\text { (kg) }\end{array}$ & $\begin{array}{l}\text { Total estimated } \\
\text { purchased volume } \\
\text { at national level } \\
\text { (kg) }\end{array}$ & $\begin{array}{l}\text { Average \% } \\
\text { purchased } \\
\text { in Nepal }\end{array}$ & & & $\begin{array}{l}\text { Total estimated } \\
\text { accumulated } \\
\text { value at national } \\
\text { level (USD) }\end{array}$ & Collec-tors & Domesti-cators & $\begin{array}{l}\text { Local } \\
\text { traders }\end{array}$ & $\begin{array}{c}\text { Sub-local } \\
\text { permanent } \\
\text { traders }\end{array}$ & $\begin{array}{c}\text { Local } \\
\text { specialist } \\
\text { traders }\end{array}$ & $\begin{array}{c}\text { Local } \\
\text { generalist } \\
\text { traders }\end{array}$ & $\begin{array}{c}\text { Central } \\
\text { whole-salers }\end{array}$ & $\begin{array}{c}\text { Regional } \\
\text { whole-salers }\end{array}$ & $\begin{array}{c}\text { Own } \\
\text { produc-tion }\end{array}$ \\
\hline & & $1,750,176$ & $3,678,854$ & 97.8 & & & $4,022,886$ & 16.9 & 1.7 & 0.4 & 0.2 & 9.4 & 6.7 & 50.0 & 0.8 & 13.9 \\
\hline
\end{tabular}

${ }^{1}$ Terminology according to [53], ${ }^{2}$ For the product type (e.g., fruit, root, bark) see the overview in [26] that is also the source of the scientific names. 


\section{References}

1. World Bank. Strategic Segmentation Analysis: Nepal. Medicinal and Aromatic Plants; World Bank Group: Washington, DC, USA, 2018. Available online: http://documents.worldbank.org/curated/en/496421556737648 658/Medicinal-and-Aromatic-Plants (accessed on 1 June 2020).

2. Vasisht, K.; Sharma, N.; Maninder, K. Current perspective in the international trade of medicinal plants material: An update. Curr. Pharm. Des. 2016, 22, 4288-4366. [CrossRef] [PubMed]

3. Smith-Hall, C.; Larsen, H.O.; Pouliot, M. People, plants and health: A conceptual framework for assessing changes in medicinal plant consumption. J. Ethnobiol. Ethnomed. 2012, 8, 43. [CrossRef] [PubMed]

4. Cunningham, A.B.; Brinckmann, J.; Pei, S.-J.; Luo, P.; Schippmann, U. Paris in the spring: A review of trade, conservation and opportunities in the shift from wild harvest to cultivation of Paris polyphylla (Trilliaceae). J. Ethnopharmacol. 2018, 222, 208-216. [CrossRef] [PubMed]

5. Homma, A.K.O. Modernisation and technological dualism in the extractive economy in Amazonia. In Current Issues in Non-Timber Forest Products Research; Ruiz Pérez, M., Arnold, J.E.M., Eds.; CIFOR: Bogor, Indonesia, 1996; pp. 59-81. Available online: http://www.cifor.org/ntfpcd/pdf/ntfp-current.pdf (accessed on 1 June 2020).

6. Noorhosseini, S.A.; Fallahi, E.; Damalas, C.A. Promoting cultivation of medicinal and aromatic plants for natural resource management and livelihood enhancement in Iran. Environ. Dev. Sustain. 2019, 22, 4007-4024. [CrossRef]

7. Pordié, L.; Hardon, A. Drugs' stories and itineraries: On the making of Asian industrial medicines. Med. Anthropol. 2015, 22, 1-6. [CrossRef] [PubMed]

8. Kessler, R.C.; Davis, R.B.; Foster, D.F.; Rompay, M.I.V.; Walters, E.E.; Wilkey, S.A.; Kaptchuk, T.J.; Eisenberg, D.M. Long-term trends in the use of complementary and alternative medical therapies in the United States. Ann. Intern. Med. 2001, 135, 262-268. [CrossRef] [PubMed]

9. Ernst, E.; Fugh-Berman, A. Complementary and alternative medicine: What is it all about? Occup. Environ. Med. 2002, 59, 140-144. [CrossRef]

10. Scheinman, D. Traditional Medicine in Tanga Today: The Ancient and Modern Worlds Meet, Indigenous Knowledge (IK); Notes No. 51; World Bank: Washington, DC, USA, 2002. Available online: http://documents.worldbank.org/curate d/en/125771468760788645/Traditional-medicine-in-Tanga-today-the-ancient-and-modern-worlds-meet (accessed on 1 June 2020).

11. Pauls, T.; Franz, M. Trading in the dark-The medicinal plants production network in Uttrakhand. Singap. J. Trop. Geogr. 2013, 34, 229-243. [CrossRef]

12. Smith-Hall, C.; Chapagain, A.; Das, A.K.; Ghimire, S.K.; Pyakurel, D.; Treue, T.; Pouliot, M. Trade and Conservation of Medicinal and Aromatic Plants_An Annotated Bibliography for Nepal; Central Department of Botany, Tribhuvan University, Sopan Press: Kathmandu, Nepal, 2020.

13. Kala, C.P. Medicinal and aromatic plants: Boon for enterprise development. J. Appl. Res. Med. Aromat. Plants 2015, 2, 134-139. [CrossRef]

14. Chandra, P.; Sharma, V. Strategic marketing prospects for developing sustainable medicinal and aromatic plants businesses in the Indian Himalayan Region. Small-Scale For. 2018, 17, 423-441. [CrossRef]

15. Kuniyal, C.P.; Bisht, V.K.; Negi, J.S.; Bhatt, V.P.; Bisht, D.S.; Butola, J.S.; Sundriyal, R.C.; Singh, S.K. Progress and prospect in the integrated development of medicinal and aromatic plants (MAPs) sector in Uttarakhand, Western Himalaya. Environ. Dev. Sustain. 2015, 17, 1141-1162. [CrossRef]

16. Astutik, S.; Pretzsch, J.; Kimengsi, J.N. Asian medicinal plants' production and utilization potentials: A review. Sustainability 2019, 11, 5483. [CrossRef]

17. Badini, O.S.; Hajjar, R.; Kozak, R. Critical success factors for small and medium forest enterprises: A review. For. Policy Econ. 2018, 94, 35-45. [CrossRef]

18. Cunningham, A.B. Non-timber products and markets: Lessons for export-oriented enterprise development from Africa. In Non-Timber Forest Products in the Global Context; Shackleton, S., Shackleton, C., Shanley, P., Eds.; Springer: Berlin, Germany, 2011; pp. 83-106. [CrossRef]

19. Meinhold, K.; Darr, D. The processing of non-timber forest products through small and medium enterprises-A review of enabling and constraining factors. Forests 2019, 10, 1026. [CrossRef]

20. Saxer, M. Herbs and traders in transit: Border regimes and the contemporary trans-Himalayan trade in Tibetan medicinal plants. Asian Med. 2009, 5, 317-339. [CrossRef] 
21. Kloos, S.; Madhavan, H.; Tidwell, T.; Blaikie, C.; Cuomu, M. The transnational Sowa Rigpa industry in Asia: New perspectives on an emerging economy. Soc. Sci. Med. 2020, 245, 112617. [CrossRef]

22. Bode, M. Taking traditional knowledge to the market: The commoditization of Indian medicine. Med. Anthropol. 2006, 13, 225-236. [CrossRef]

23. Biesen, C.M.Z. From coastal to global: The transnational flow of ayurveda and its relevance for Indo-African linkages. Glob. Public Health 2016, 13, 339-354. [CrossRef]

24. Harilal, M.S. Commercialising traditional medicine: Ayurvedic manufacturing in Kerala. Econ. Polit. Wkly. 2009, 16, 44-51. Available online: https://www.jstor.org/stable/40279155 (accessed on 1 June 2020).

25. Makunga, N.P.; Philander, L.E.; Smith, M. Current perspectives on an emerging formal natural products sector in South Africa. J. Ethnopharmacol. 2008, 119, 365-375. [CrossRef]

26. Pyakurel, D.; Smith-Hall, C.; Bhattarai-Sharma, I.; Ghimire, S.K. Trade and conservation of Nepalese medicinal plants, fungi, and lichens. Econ. Bot. 2019, 73, 505-521. [CrossRef]

27. Olsen, C.S. Valuation of commercial central Himalayan medicinal plants. Ambio 2005, 34, 607-610. [CrossRef] [PubMed]

28. Pouliot, M.; Pyakurel, D.; Smith-Hall, C. High altitude organic gold: The production network for Ophiocordyceps sinensis from far-western Nepal. J. Ethnopharmacol. 2018, 218, 59-68. [CrossRef] [PubMed]

29. Olsen, C.S.; Larsen, H.O. Alpine medicinal plant trade and Himalayan mountain livelihood strategies. Geogr. J. 2003, 169, 243-254. [CrossRef]

30. Sharma, P.; Shrestha, N. Promoting Exports of Medicinal and Aromatic Plants (MAPs) and Essential Oils from Nepal; WTO/EIF Support Programme: Kathmandu, Nepal, 2011. Available online: http://sawtee.org/Researc h_Reports/R2011-04.pdf (accessed on 1 June 2020).

31. Chapagain, A.; Kafle, G.; Das, A.K.; Caporale, F.; Mateo-Martín, J.; Usman, F.; Pouliot, M.; Smith-Hall, C. A Population List of Medicinal Plant Processing Enterprises in Nepal; IFRO Documentation 2019/3; Department of Food and Resource Economics, University of Copenhagen: Copenhagen, Denmark, 2019. Available online: https://static-curis.ku.dk/portal/files/230394492/IFRO_Documentation_2019_3.pdf (accessed on 1 June 2020).

32. Paudel, N.S.; Adhikary, A.; Mbairamadji, J.; Nguyen, T.Q. Small-Scale Forest Enterprise Development in Nepal; Overview, Issues and Challenges; FAO: Rome, Italy, 2018; ISBN 978-92-5-131130-1.

33. Subedi, B.P. Linking Plant-Based Enterprises and Local Communities to Biodiversity Conservation in Nepal Himalaya; Adroit Publishers: New Delhi, India, 2006; ISBN 81-87392-70-3.

34. DFRS (State of Nepal's Forests). Forest Resource Assessment (FRA) Nepal; Department of Forest Research and Survey: Kathmandu, Nepal, 2015. Available online: http://nkcs.org.np/dfrs/ecfl/pages/view.php?ref=567\&k= (accessed on 1 June 2020).

35. Olsen, C.S.; Helles, F. Market efficiency and benefit distribution in medicinal plant markets: Empirical evidence from South Asia. Int. J. Biodivers. Sci. Ecosyst. Serv. Manag. 2009, 5, 53-62. [CrossRef]

36. Pyakurel, D.; Sharma, I.B.; Smith-Hall, C. Patterns of change: The dynamics of medicinal plant trade in far-western Nepal. J. Ethnopharmacol. 2018, 224, 323-334. [CrossRef]

37. Larsen, H.O.; Olsen, C.S.; Boon, T.E. The non-timber forest policy process in Nepal: Actors, objectives and power. For. Policy Econ. 2000, 1, 267-281. [CrossRef]

38. Larsen, H.O.; Smith, P.D.; Olsen, C.S. Nepal's conservation policy options for commercial medicinal plant harvesting: Stakeholder views. Oryx 2005, 39, 435-441. [CrossRef]

39. Pokharel, R.K.; Tiwari, K.R.; Thwaites, R. Community forestry in Nepal: Analysis of environmental outcomes. In Community Forestry in Nepal: Adapting to a Changing World; Thwaites, R., Fisher, R., Poudel, M., Eds.; Taylor \& Francis: Oxon, UK, 2017; pp. 37-58. [CrossRef]

40. Barakoti, T.P. Country status report on medicinal and aromatic plants in Nepal. In Proceedings of the Expert Consultation on Promotion of Medicinal and Aromatic Plants in the Asia-Pacific Region, Bangkok, Thailand, 2-3 December 2013; Paroda, R., Dasgupta, S., Mal, B., Ghosh, S.P., Pareek, S.K., Eds.; Asia-Pacific Association of Agricultural Research Institutions (APAARI): Bangkok, Thailand, 2014; pp. 124-138. Available online: http://www.apaari.org/wp-content/uploads/downloads/2014/10/Medicinal-and-Aromatic-PlantsProceedings_21-10-2014-1.pdf (accessed on 1 June 2020).

41. Olsen, C.S. The trade in medicinal and aromatic plants from central Nepal to northern India. Econ. Bot. 1998, 52, 279-292. [CrossRef] 
42. Macqueen, D.J. The role of small and medium forest enterprise associations in reducing poverty. In A Cut for the Poor, Proceedings of the International Conference on Managing Forests for Poverty Reduction: Capturing Opportunities in Forest Harvesting and Wood Processing for the Benefit of the Poor, Ho Chi Minh City, Vietnam, 3-6 October 2006; Oberndorf, R., Durst, P., Mahanty, S., Burslem, K., Suzuki, R., Eds.; FAO RAP Publication 2007/09 and RECOFTC Report 19; FAO: Bangkok, Thailand, 2007; pp. 192-203. Available online: http: //www.fao.org/3/ag131e/ag131E00.htm (accessed on 1 June 2020).

43. Larsen, H.O.; Olsen, C.S. Unsustainable collection and unfair trade? Uncovering and assessing assumptions regarding central Himalayan medicinal plant conservation. Biodivers. Conserv. 2007, 16, 1679-1697. [CrossRef]

44. Kunwar, R.M.; Adhikari, Y.P.; Sharma, H.P.; Rimal, B.; Devkota, H.P.; Charmakar, S.; Acharya, R.P.; Baral, K.; Ansari, A.S.; Bhattarai, R.; et al. Distribution, use, trade and conservation of Paris polyphylla Sm. in Nepal. Glob. Ecol. Conserv. 2020, 23, e01081. [CrossRef]

45. Bugge, M.M.; Hansen, T.; Klitkou, A. What is the bioeconomy? A review of the literature. Sustainability 2016, 8, 691. [CrossRef]

46. Smith, T.; Beagley, L.; Bull, J.; Milner-Gulland, E.J.; Smith, M.; Vorhies, F.; Addison, P.F.E. Biodiversity means business: Reframing global biodiversity goals for the private sector. Conserv. Lett. 2020, 13, e12690. [CrossRef]

47. Henderson, J.; Dicken, P.; Hess, M.; Coe, N.; Yeung, H.W.C. Global production networks and the analysis of economic development. Rev. Int. Polit. Econ. 2002, 9, 436-464. [CrossRef]

48. Smith-Hall, C.; Pouliot, M.; Pyakurel, D.; Fold, N.; Chapagain, A.; Ghmire, S.; Meilby, H.; Kmoch, L.; Chapagain, D.J.; Das, A.; et al. Data Collection Instruments and Procedures for Investigating National-Level Trade in Medicinal and Aromatic Plants: The Case of Nepal; IFRO Documentation 2018/2; Department of Food and Resource Economics, University of Copenhagen: Copenhagen, Denmark, 2018. Available online: https://curis.ku.dk/portal/files/196408842/IFRO_Documentation_2018_2.pdf (accessed on 1 June 2020).

49. Adam, Y.O.; Pettenella, D. The contribution of small-scale forestry-based enterprises to the rural economy in the developing world: The case of the informal carpentry sector, Sudan. Small Scale For. 2002, 12, 461-474. [CrossRef]

50. Marshall, E. Health and Wealth from Medicinal Aromatic Plants; FAO Diversification Booklet 17; FAO: Rome, Italy, 2011; ISBN 978-92-5-107070-3.

51. Fellows, P. Processing for Prosperity, 2nd ed.; FAO Diversification Booklet 5; FAO: Rome, Italy, 2011. Available online: http://www.fao.org/3/a-i2468e.pdf (accessed on 1 June 2020).

52. Fellows, P. Value from Village Processing, 2nd ed.; FAO Diversification Booklet 4; FAO: Rome, Italy, 2011. Available online: http://www.fao.org/3/i2467e/i2467e00.pdf (accessed on 1 June 2020).

53. Olsen, C.S.; Bhattarai, N. A typology of economic agents in the Himalayan plant trade. Mount. Res. Dev. 2005, 25, 37-44. [CrossRef]

54. UNEP. Green Economy Sector Study. Biotrade: Harnessing the Potential for Transitioning to a Green Economy-The Case of Medicinal and Aromatic Plants in Nepal; United Nations Environment Programme: Geneva, Switzerland, 2012. Available online: https://wedocs.unep.org/bitstream/handle/20.500.11822/25917/biotrade_Nepal.pdf?s equence $=1 \&$ isAllowed $=y$ (accessed on 1 June 2020).

55. Pant, P.R.; Dangol, D. Kathmandu Valley profile. In Proceedings of the Governance and Infrastructure Development Challenges in the Kathmandu Valley Workshop, Kathmandu, Nepal, 11-13 February 2009. Available online: https://www.eastwestcenter.org/fileadmin/resources/seminars/Urbanization_Seminar/Kat hmandu_Valley_Brief_for_EWC__KMC_Workshop_Feb_2009_.pdf (accessed on 1 June 2020).

56. Tiwari, S.; Bhattarai, K. Migration, Remittances and Forests: Disentangling the Impact of Population and Economic Growth on Forests; World Bank, Policy Research Working Paper 5907; World Bank: Washington, DC, USA, 2004. [CrossRef]

57. Coe, N.M.; Yeung, H.W.-C. Global Production Networks: Theorizing Economic Development in an Interconnected World; Oxford University Press: Oxford, UK, 2015. [CrossRef]

58. Kafle, G.; Bhattarai-Sharma, I.; Siwakoti, M.; Shrestha, A.K. Demand, end-uses, and conservation of alpine medicinal plant Neopicrorhiza scrophulariiflora (Pennell) D.Y. Hong in central Himalaya. Evid. Based Complement. Altern. Med. 2018, 2018. [CrossRef]

59. Sharma, U.R. Medicinal and aromatic plants: A growing commercial sector of Nepal. Initiation 2007, 1, 4-8. [CrossRef] 
60. Goraya, G.S.; Ved, D.K. Medicinal Plants in India: An Assessment of their Demand and Supply; National Medicinal Plants Board, Ministry of AYUSH, Government of India; New Delhi and Indian Council of Forestry Research \& Education: Dehradun, India, 2017; ISBN 978-81-211-0628-3.

61. Cunningham, A.B.; Brinckmann, J.A.; Yang, X.; He, J. Introduction to the special issue: Saving plants, saving lifes: Trade, sustainable harvest and conservation of traditional medicinals in Asia. J. Ethnopharmacol. 2019, 229, 288-292. [CrossRef]

62. Hinsley, A.; Milner-Gulland, E.J.; Cooney, R.; Timoshyna, A.; Ruan, X.; Lee, T.M. Building sustainability into the belt and road initiative's traditional Chinese medicine trade. Nat. Sustain. 2020, 3, 96-100. [CrossRef]

63. Meilby, H.; Smith-Hall, C.; Byg, A.; Larsen, H.O.; Nielsen, Ø.J.; Puri, L.; Rayamajhi, S. Are forest incomes sustainable? Firewood and timber extraction and forest productivity in community managed forests in Nepal. World Dev. 2014, 64, S113-S124. [CrossRef]

64. National Planning Commission. Preliminary Results of National Economic Census 2018 of Nepal; National Planning Commission, Central Bureau of Statistics: Kathmandu, Nepal, 2019. Available online: https://cbs.gov.np/wp-content/upLoads/2018/12/NEC2018-Preliminary-Results-National-ReportNo.1-complete-set-final-rev6-180916.pdf (accessed on 1 June 2020).

65. Collier, P. The Plundered Planet; Penguin Books: London, UK, 2010; ISBN 978-0-1410-4214-5.

66. National Planning Commission. Sustainable Development Goals, 2016-2030. National (Preliminary) Report; National Planning Commission, Central Bureau of Statistics: Kathmandu, Nepal, 2015. Available online: https: //www.undp.org/content/dam/nepal/docs/reports/SDG\%20final\%20report-nepal.pdf (accessed on 1 June 2020).

67. Cosic, D.; Dahal, S.; Kitzmuller, M. Climbing Higher: Toward a Middle-Income Nepal. Country Economic Memorandum; The World Bank: Washington, DC, USA, 2017. [CrossRef]

68. MoC. Nepal Trade Integration Strategy (NTIS); Ministry of Commerce: Kathmandu, Nepal, 2016. Available online: https://www.oecd.org/aidfortrade/countryprofiles/dtis/Napal-DTIS-2016.pdf (accessed on 1 June 2020).

69. World Bank. Doing Business 2020: Comparing Business Regulation in 190 Economies-Economy Profile of Nepal (English); World Bank Group: Washington, DC, USA, 2019.

70. Childs, G.; Craig, S.; Beall, C.M.; Basnyat, B. Depopulating the Himalayan highlands: Education and outmigration from ethnically Tibetan communities of Nepal. Mt. Res. Dev. 2014, 34, 85-94. [CrossRef]

71. Mala, W.A.; Tieguhong, J.C.; Ndoye, O.; Grouwels, S.; Betti, J.L. Collective action and promotion of forest based associations on non-wood forest products in Cameroon. Dev. Pract. 2012, 22, 1122-1134. [CrossRef]

72. Baral, S.; Meilby, H.; Chettri, B.B.K.; Basnyat, B.; Rayamajhi, S.; Awale, S. Politics of getting the numbers right: Community forest inventory of Nepal. For. Policy Econ. 2018, 91, 19-26. [CrossRef]

73. Basnyat, B.; Treue, T.; Pokharel, R.K. Bureaucratic recentralisation of Nepal's community forestry sector. Int. For. Rev. 2019, 21, 401-415. [CrossRef]

74. Kunwar, R.M.; Mahat, L.; Acharya, R.P.; Bussmann, R.W. Medicinal plants, traditional medicine, markets and management in far-west Nepal. J. Ethnobiol. Ethnomed. 2013, 9, 24. [CrossRef]

75. Maneesha, S.; Deep, S. Zanthoxylum armatum DC: Past, present and future prospective. Biotech Today Int. J. Biol. Sci. 2017, 7, 21-24.

76. IPCC. Climate Change and land: An IPCC Special Report on Climate Change, Desertification, Land Degradation, Sustainable Land Management, Food Security, and Greenhouse Gas Fluxes in Terrestrial Ecosystems. Summary for Policymakers; IPCC: Geneva, Switzerland, 2020; ISBN 978-92-9169-154-8.

77. Staffas, L.; Gustavsson, M.; McCormick, K. Strategies and policies for the bioeconomy and bio-based economy: An analysis of official national approaches. Sustainability 2013, 5, 2751-2769. [CrossRef]

(C) 2020 by the authors. Licensee MDPI, Basel, Switzerland. This article is an open access article distributed under the terms and conditions of the Creative Commons Attribution (CC BY) license (http://creativecommons.org/licenses/by/4.0/). 